\title{
Preliminary Research on Air Passenger Volume Variation in Kilimanjaro International Airport Tanzania
}

\author{
Freddy David Chilongola ${ }^{1, a)}$, Hitapriya Suprayitno ${ }^{2, b)}$ \& Dewanti ${ }^{3 . c)}$ \\ ${ }^{1)}$ Tanzania Civil Aviation Authority, Kilimanjaro, Tanzania. \\ ${ }^{2)}$ Civil Engineering Dept., Institut Teknologi Sepuluh Nopember (ITS), Surabaya, Indonesia. \\ ${ }^{3)}$ Civil \& Environmenal Engineering Dept., Universitas Gadjah Mada, Yogyakarta, Indonesia. \\ Correspondent : ${ }^{a)}$ freddychilo1@gmail.com, ${ }^{b}$ suprayitno.hita@gmail.com \& ${ }^{c}$ dewanti@ugm.ac.id.
}

\begin{abstract}
Airport Management needs data on Passenger Volume. Passenger Volume varies annually, monthly, weekly, daily, and hourly. A different aspect of Airport Management needs different data on Pasengger Volume Variation. Each airport has its Variation Characteristics. Kilimanjaro International Airport is a unique airport, as it is located close to a Mountain Kilimanjaro. Knowing it's Passenger Volume Variation is important. Three Variations have been observed, the monthly, the weekly, and the hourly. The monthly variation shows that the high season happens from July to October. Based on three months of data, the weekly variation shows the inconsistency of the variation pattern. The weekly index of variation could not be developed. While the daily variation shows that high daily volume exists from Friday to Sunday.
\end{abstract}

Keywords: infrastructure asset management, airport, air passenger variation.

\section{INTRODUCTION}

An Airport is a basic transportation infrastructure for practically all of the countries in the world. International passenger transports are dominated by air transport, due to its distances. Archipelago countries, like Great Britain, Japan, the Philipines and Indonesia, their domestic inter-island transport depend on air transport. Tiny island countries, in the Pacific and Caribean, need absolutely air transport, for international movement. Vast countries, like the United States, Canada, Russia, Australia, Brazil, China, and the others, must use air transport for their domestic passenger transport.

Kilimanjaro International Airport (KIA) is the second largest airport after Julius Nyerere International Airport in terms of the number of air traffic and passengers in Tanzania. Kilimanjaro International Airport is the gateway to the northern tourism circuit which is East Africa's best tourist destination, contains several national parks, including the Mt. Kilimanjaro.

An airport can be said, consists of the airside, the landside, and the interface between the two. The airside consists of the runway, the taxiway, and the apron. The landside consists of the access road, the parking area, and the drop-pickup zone. While the interface of these twos is the passenger terminal (Horonjeff \& McKelvey, 1994; Sartono, Dewanti, \& Rahman, 2019).

The airport must be managed based on the infrastructure asset management principle. It's whole life steps must be well managed so that the airport can always function well. The life steps include airport development, operation, and maintenance aspects, apart from the other aspects (Soemitro \& Suprayitno, 2018; Suprayitno \& Soemitro, 2018). All of these must be organized in function of the number of passenger traffic volume, thus the aircraft traffic volume also. For the different levels of management objective, the passenger data needed are different, and all always deal with the passenger demand variation (Alblaster, 2018; Horonjeff \& McKelvey, 1994; Lestari, Dewanti \& Priyanto, 2020). Estimating air passenger demand is 
required in making decisions and formulating policies for airport development. (Sefrus, et.al, 2020). Wang and Pitfield (1999) indicate that airport size leads to a different impact on the use of air passenger data in design peak hour derivation. Examining a linear model of arriving traffic offers a poorer explanation for small airports although a better one for large airports.

This paper presents the result of mini-research to develop a passenger variation pattern at Kilimanjaro International Airport, located in Tanzania.

\section{RESEARCH METHOD}

This Preliminary Research was done by following these steps. The research was started by understanding the Use of Air Passenger Demand Variation Characteristics, followed by underlining the Kilimanjaro International Airport, after that collecting the secondary data, and subsequently developing the index of variation calculation. The analysis of passenger volume variation was still simple, by using the Index of Variation. Its formula is simple arithmetic purpose-developed formula.

\section{AIR PASSENGER VOLUME VARIATION ANALYSIS}

\section{The Use of Air Passenger Demand Variations}

Air Passenger Demand Variation is needed for Airport Development Plan, the Runway Operation Plan, the Terminal Development Design, the Terminal Operation Plan, and other aspects related to Airport (Alblaster, 2018; Çuhadar, 2014; Sartono, Dewanti \& Rahman, 2019; Suprayitno, 2020; Supayitno, 2020a).

Airport Master Plan, normally, is developed based on Annual Passenger Traffic Volume predicted for the Airport Master Plan stage year and horizon year (Madhwal \& Avdeeva, 2017; Suprayitno, 2020; Suprayitno, 2020a). Terminal Development Design has to incorporate the seasonal factor, which means based on Monthly Passenger Demand (Mao et al, 2015; Robertson \& Wallin, 2014; Suryani et al, 2010). Terminal Operation Plan, includes the Facilities needed, normally is based on Daily and Hourly Passenger Demand Variation (Ahyudanari \& Vendebona, 2009; Çuhadar, 2014; Hamzah, Dewanti, Muthohar, 2020), the same as for Sea Passenger Terminal (Suprayitno, Pambudi, Cahyono, 2017).

Therefore, Air Passenger Demand Variations are needed. These are from the annual growth, the monthly (seasonal) variations, the weekly variations, the daily variations, down to the hourly variations.

\section{Kilimanjaro International Airport}

Kilimanjaro International Airport is strategically located between regions of Kilimanjaro and Arusha in East Africa, Tanzania. It is 23 NM ESE from the city of Arusha and 16 NM WSW from Moshi. (TCAA, 2020). The airport opened in 1971 and famously known as The Gateway to Africa's Wildlife Heritage.

Kilimanjaro International Airport operated by Kilimanjaro Airport Development Company Ltd (KADCO), a company now fully owned by the government of Tanzania since 1998 in the $110 \mathrm{~km}^{2}$ area of land. The airport located between Arusha and Moshi due to the potential of tourism and business opportunities for the two cities. It is few kilometers away from the highest standing mountain in Africa Mount Kilimanjaro and famous national parks such as Ngorongoro Crater, Serengeti, Lake Manyara, Mkomazi, Tarangire to mention the few. It is important also for cargo flight due to the climates condiction and fertile land hence the exportation of crops and animal products such as maize, onions, coffee, beans, banana, flowers to Europe, Middle East, and the Far East. Passenger and freight flows are the consequences of spatial interaction between various regions. Various socio-economic activities in a society, as well as land-uses, highly influence transportation demand (Teodorovic \& Janic, 2017). 
Airports in Tanzania are categorized into three categories, category A, category B, and Category C. Kilimanjaro International Airport is in category A which contains International airport (TCAA, 2020). The airport is operating in 24 hours and the services provided are Customs and Immigration, Aeronautical Information Services (AIS), Air Traffic Services (ATS), fueling, MET Briefing Office, Handling, Health, and Sanitation.

Passenger facilities available are hotels, restaurants, shuttle, taxi to Moshi and Arusha, medical Facilities, tourist office, bank, and Post office. There are cargo and one passenger terminal which serves domestic and international flights. Daily domestic flight to Zanzibar, Mwanza, Dar es Salaam, Arusha, and national parks such as Seronera, Lake Manyara, Ndutu, etc. The Airport has direct flights to Kenya, Netherland, Rwanda, Turkey, Ethiopia, Oman, Qatar, and Uganda.

The runway length at KIA is $3600 \mathrm{~m}$ long and $45 \mathrm{~m}$ wide. Elevation and reference temperature are $2932 \mathrm{ft}$ and $33^{\circ} \mathrm{C}$, airspace classification is Class D, ICAO, and IATA code HTKJ and JRO respectively (TCAA, 2020; ICAO Doc. 7910).

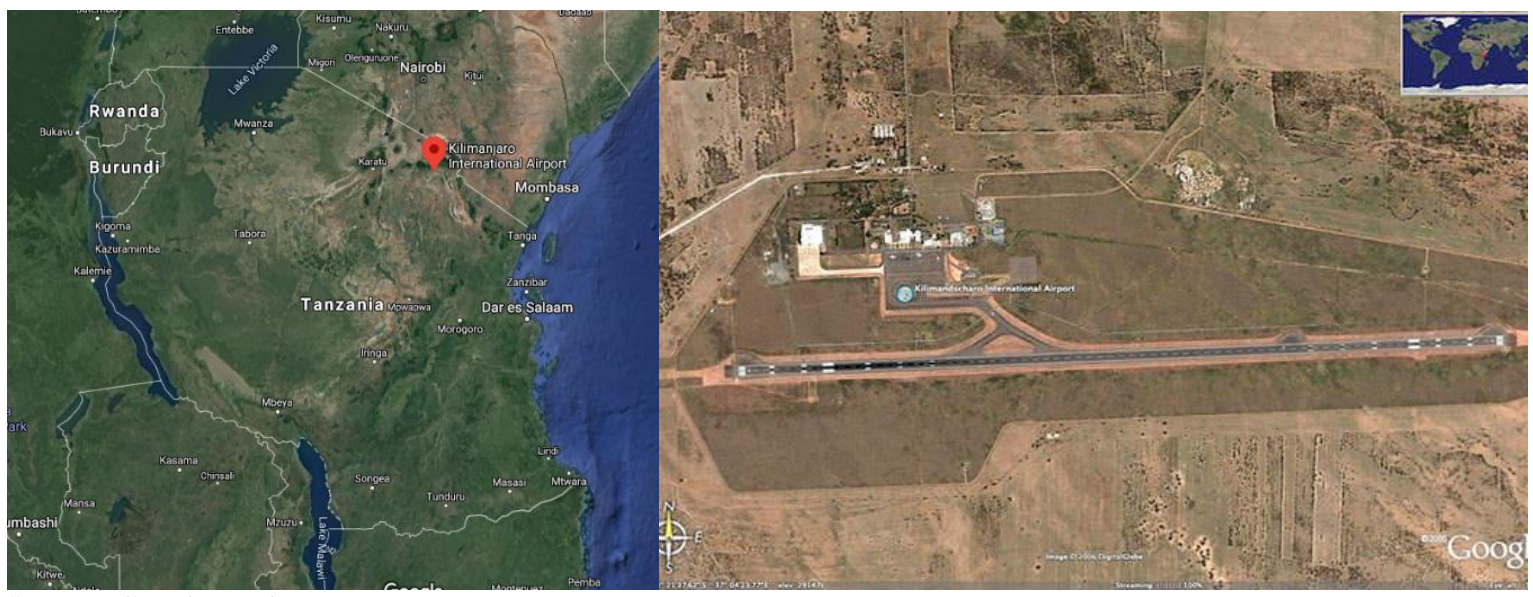

Source : Google Earth

Figure 1. Location Map and Plan of Kilimanjaro International Airport

\section{Monthly Variation of Passenger Volume}

Two years of 2018 and 2019 data were used to analyze for the Monthly Variation Characteristics. The monthly variation characteristics must be seen based on the average monthly data. To make the monthly variation characteristics be seen more clearly, the Index of Variation for Monthly Passenger Volume was calculated by using the following Formula.

$$
I V_{m p v}=\frac{\bar{V}_{m}}{\bar{V}_{v m}}
$$

Where :

$\mathrm{IV}_{\mathrm{mpv}} \quad$ : Index of Variation for Monthly Passenger Volume.

$\bar{V}_{\mathrm{m}} \quad$ : Average of Monthly Passenger Volume, across several years

$\bar{V}_{\mathrm{vm}} \quad$ : Average of $\bar{V}_{m}$, for 12 months.

Calculation of Index of Variation for Monthly Passenger Volume shows that the highseason exists between July to October due to the high season of tourism in Tanzania, while the low-season exists during April and May. The data and calculation results are presented in Table 1, Figure 2, and Figure 3 as follows. 
e)ISSN 2656-8896 (p)ISSN 2656-890X

Journal of Infrastructure and Facility Asset Management - Vol. 2, Issue. 2, September 2020

Table 1. Monthly Variation of Passenger Volume in Kilimanjaro International Airport

\begin{tabular}{clrrrr}
\hline \multirow{2}{*}{ No. Month } & \multicolumn{2}{c}{ Year } & Average & $\begin{array}{c}\text { Monthly } \\
\text { Index }\end{array}$ \\
& & & $\mathbf{2 0 1 8}$ & $\bar{V}_{m}$ & IV $_{\text {mpv }}$ \\
& & pass/month & pass/month & pass/month & \\
\hline 1 & January & 72,204 & 73,358 & $72,781.0$ & 0.941 \\
2 & February & 71,262 & 74,133 & $72,697.5$ & 0.939 \\
3 & March & 66,805 & 71,954 & $69,379.5$ & 0.897 \\
4 & April & 54,600 & 52,231 & $53,415.5$ & 0.690 \\
5 & May & 51,239 & 58,870 & $55,054.5$ & 0.711 \\
6 & June & 84,096 & 74,469 & $79,282.5$ & 1.025 \\
7 & July & 108,825 & 96,606 & $102,715.5$ & 1.327 \\
8 & August & 110,815 & 88,099 & $99,457.0$ & 1.285 \\
9 & September & 90,980 & 84,680 & $87,830.0$ & 1.135 \\
10 & October & 92,090 & 84,557 & $88,323.5$ & 1.141 \\
11 & November & 75,024 & 65,652 & $70,338.0$ & 0.909 \\
12 & December & 82,263 & 72,335 & $77,299.0$ & 0.999 \\
\hline \multicolumn{5}{c}{$\bar{V}_{v m}$} & $77,381.1$ \\
\hline
\end{tabular}

source : KADCO and ACI Annual Report

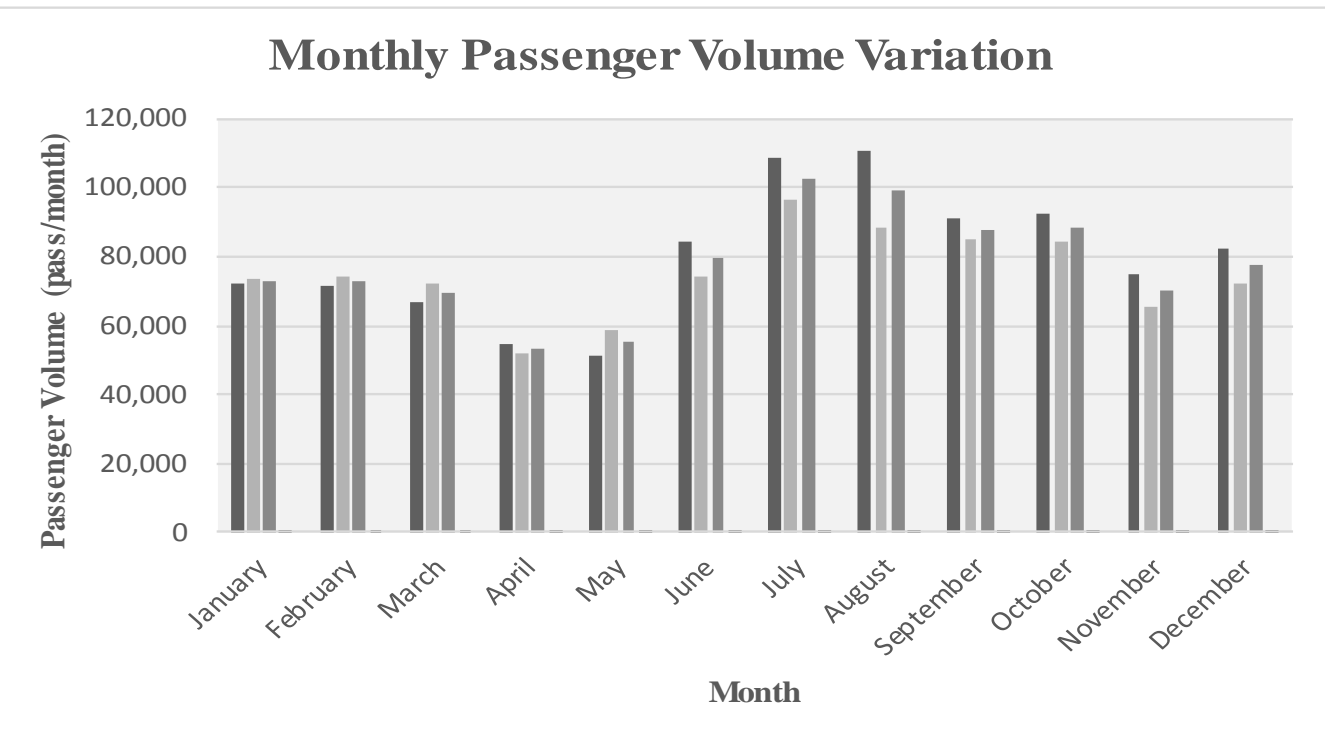

Figure 2. Monthly Passenger Volume Variation 


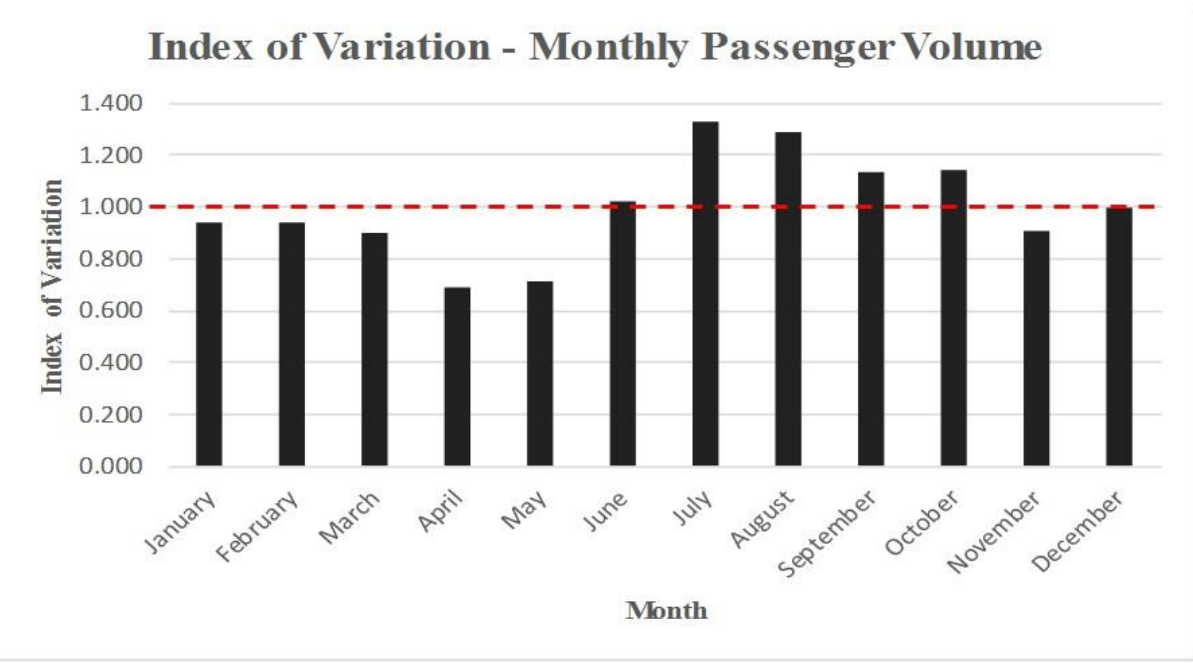

Figure 3. Index of Variation for Monthly Passenger Volume

\section{Weekly Variation of Passenger Volume}

Three Months Passenger Volume data were used to analyze the Weekly Variation of Passenger Volume. The Weekly Variation characteristics must be seen based on the average weekly data. To make the characteristics be seen more clearly, the Index of Variation for Weekly Passenger Volume was calculated by using the following Formula.

$$
I V_{w p v}=\frac{\bar{V}_{w}}{\bar{V}_{v w}}
$$

Where :

$\mathrm{IV}_{\mathrm{wpv}} \quad:$ Index of Variation for Weekly Passenger Volume

$\bar{V}_{w} \quad:$ Average Values of Weekly Passenger Volume

$\bar{V}_{v w} \quad:$ Average Value of $\bar{V}_{w}$ for several weeks.

Observation on Weekly Passenger Volume, for these three months, shows that the Weekly Passenger Volume Variation is not consistent. In January 2019, the weekly volumes are higher in the first and second weeks of the month. While, in February and March 2019, the weekly volumes are lower during the first and second weeks of the months. Therefore, the Index of Variation for Weekly Passenger Volume was not calculated. More data are needed to see the general tendency of the Weekly Passenger Volume Variation. The data are presented in Table 2 and Figure 4 as follows.

Table 2. Weekly Passenger Volume Variation in Kilimanjaro International Airport

\begin{tabular}{|c|c|c|c|c|c|}
\hline \multirow{2}{*}{ No } & \multirow{2}{*}{ Week } & \multicolumn{4}{|c|}{ Weekly Variation } \\
\cline { 3 - 6 } & & Jan-19 & Feb-19 & Mar-19 & Average \\
\hline & & pass/week & pass/week & pass/week & pass/week \\
\hline 1 & Week 1 & 19,377 & 15,678 & 14,029 & 16,361 \\
\hline 2 & Week 2 & 18,027 & 17,103 & 14,697 & 16,609 \\
\hline 3 & Week 3 & 17,834 & 20,666 & 16,701 & 18,400 \\
\hline 4 & Week 4 & 16,966 & 17,816 & 21,378 & 18,720 \\
\hline \multicolumn{7}{|c|}{} & & & $\bar{V}_{v w}$ & 17,523 \\
\hline source : KADCO and ACI Annual Report & & \\
\hline
\end{tabular}




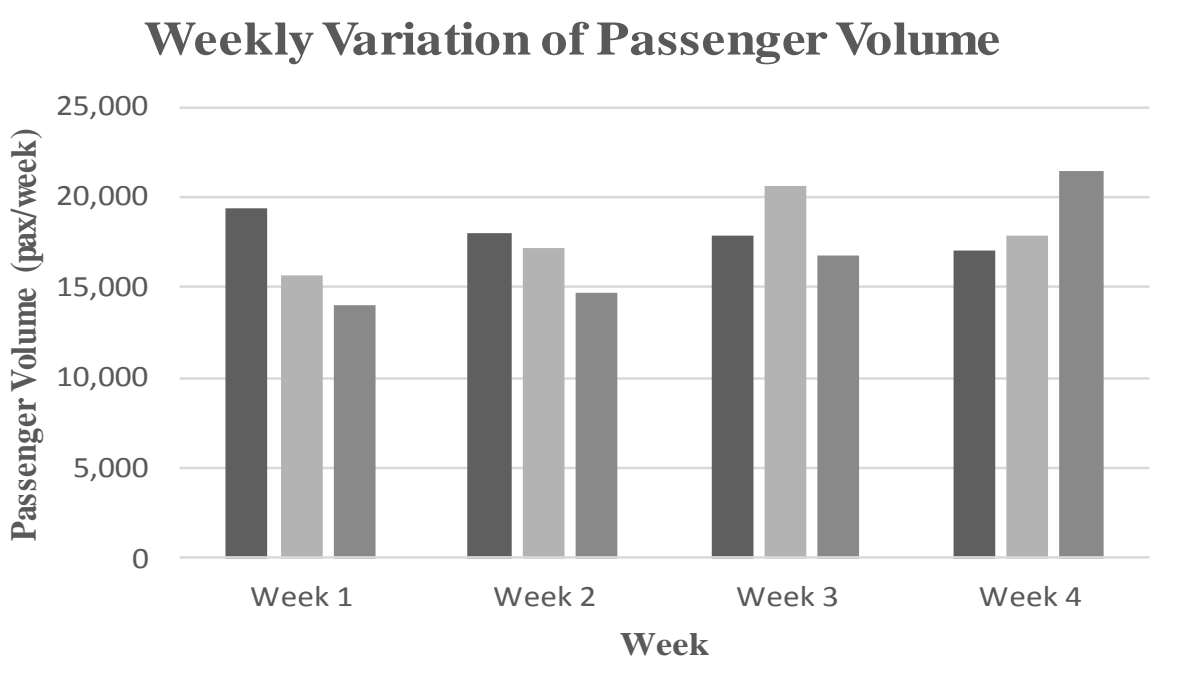

Figure 4. Weekly Passenger Volume Variation

\section{Daily Variation of Passenger Volume}

The passenger volume data of January 2019 were used to develop the Daily Variation Characteristics. The daily variation characteristics must be seen based on the average daily data. To make characteristics be seen more clearly, Index of Variation for Daily Passenger Volume was calculated by using the following Formula.

$$
I V_{d p v}=\frac{\bar{V}_{d}}{\bar{V}_{v d}}
$$

Where:

$\mathrm{IV}_{\mathrm{dpv}} \quad$ : Index of Variation for Daily Passenger Volume

$\bar{V}_{d} \quad:$ Averages of Daily Passenger Volume

$\bar{V}_{v d} \quad$ : Average Values of $\bar{V}_{d}$ Daily Passenger Volume

Observation and calculation of the Daily Passenger Volume gave us these following variations. Friday to Sunday has relatively high passenger volume. While daily passenger volume is normally low from Monday to Thursday. The data and calculation results are presented in Table 3, Figure 5, and Figure 6 as follows.

Table 3. Variation of Daily Passenger Volume in Kilimanjaro International Airport

\begin{tabular}{|c|c|c|c|c|c|c|c|}
\hline \multirow{2}{*}{ No. } & \multirow{2}{*}{ Day } & \multicolumn{4}{|c|}{ Jan-19 } & \multirow{2}{*}{ Average } & \multirow{2}{*}{$\begin{array}{l}\text { Daily } \\
\text { Index }\end{array}$} \\
\hline & & Week 1 & Week 2 & Week 3 & Week 4 & & \\
\hline & & & & & & $\bar{V}_{d}$ & $I V_{d p v}$ \\
\hline & & pass/day & pass/day & pass/day & pass/day & pass/day & \\
\hline 1 & Monday & 969 & 721 & 1,427 & 1,188 & $1,076.1$ & 0.417 \\
\hline 2 & Tuesday & 1,163 & 901 & 892 & 848 & 951.1 & 0.369 \\
\hline 3 & Wednesday & 1,356 & 1,442 & 1,248 & 1,357 & $1,351.0$ & 0.524 \\
\hline 4 & Thursday & 1,744 & 1,803 & 1,427 & 1,866 & $1,709.9$ & 0.663 \\
\hline 5 & Friday & 6,200 & 5,048 & 4,637 & 4,242 & $5,031.5$ & 1.951 \\
\hline 6 & Saturday & 5,619 & 5,588 & 3,567 & 3,054 & $4,457.0$ & 1.728 \\
\hline \multirow[t]{2}{*}{7} & Sunday & 2,325 & 2,524 & 4,637 & 4,411 & $3,474.2$ & 1.347 \\
\hline & & & & & $\bar{V}_{v d}$ & $2,578.7$ & \\
\hline
\end{tabular}




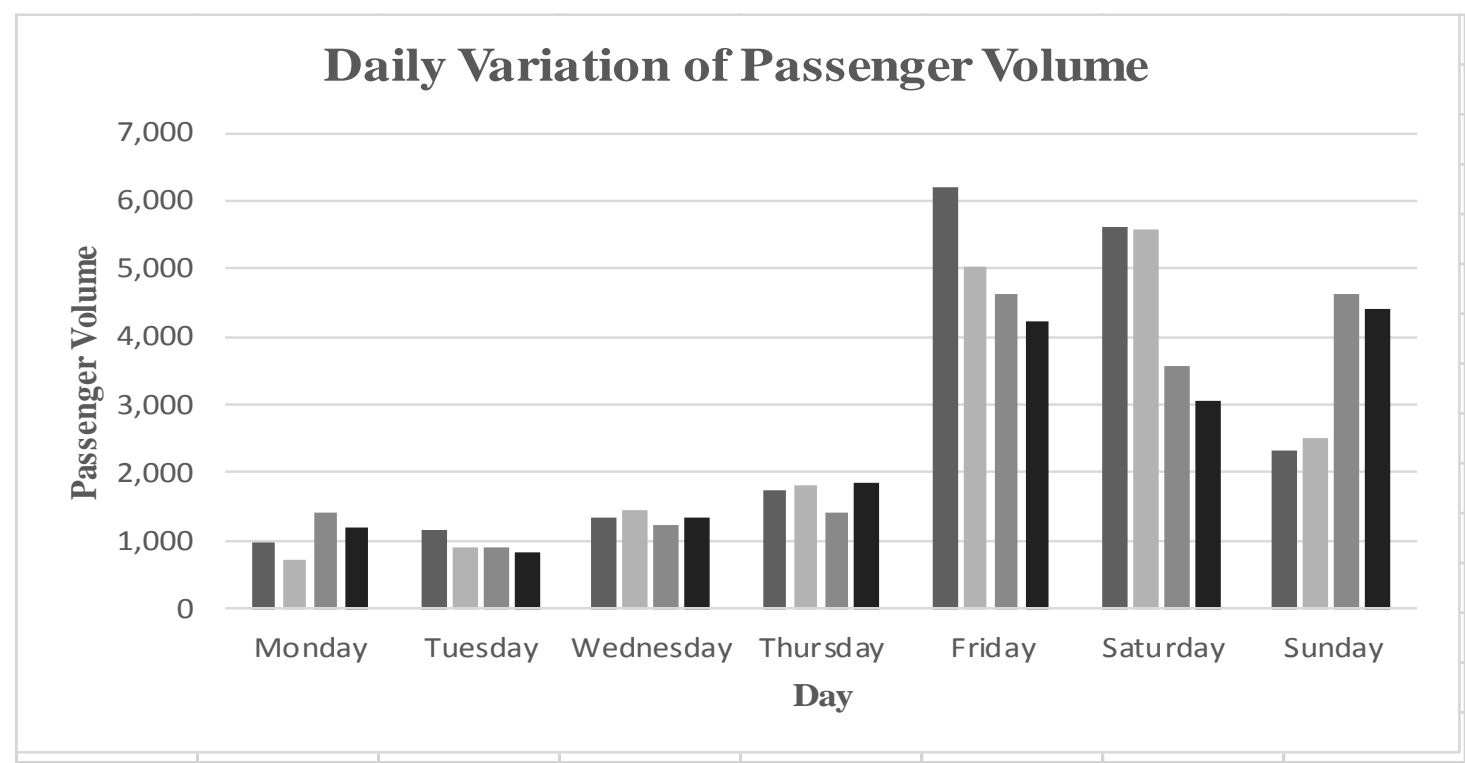

Figure 5. Daily Variation of Passenger Volume

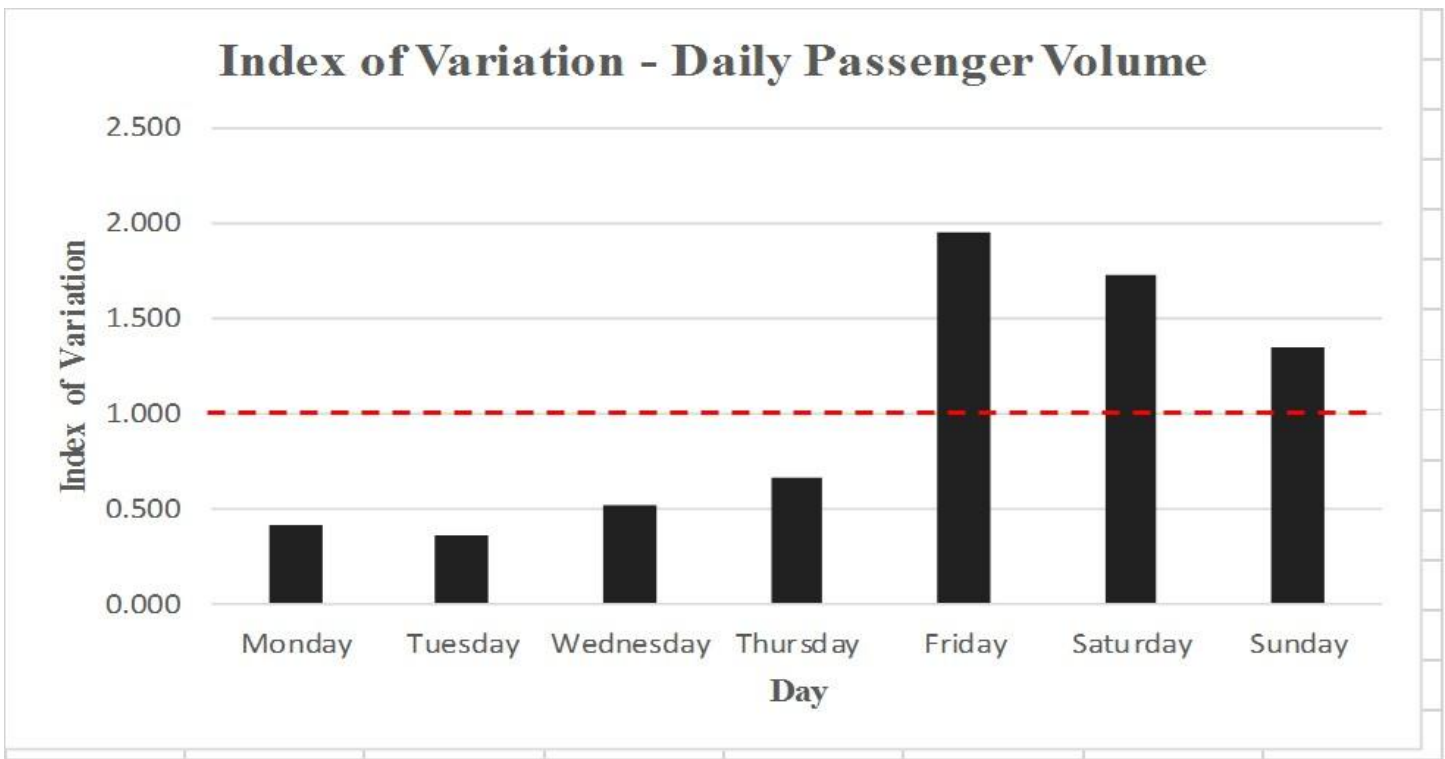

Figure 6. Index of Variation for Daily Passenger Volume

\section{CONCLUSION}

The index of variation was used to analyze the passenger demand volume variations at Kilimanjaro International Airport (KIA). The main conclusions can be drawn from this collaborative small research as following.

- The important variable of air passenger demand volume variations consist of the annual growth, the monthly variation, the weekly variation, the daily variation, and the hourly variation.

- In general, the Monthly Variation analyzes result show that high passenger volumes exist in July - October, and always low in April and May, the other months have average monthly passenger volume.

- For these three months of data, the Weekly Variation analyzed result show that the Weekly Passenger Volumes Variation are not consistent. The variation pattern of January is different from the February and March pattern. An additional period of data of other months is needed to get the general weekly variation characteristic. 
- Overall, the Daily Variation analyze result shows that daily passenger volume on Friday Sunday are always high, above the average value, while those of Monday - Thursday are always small, less than the average.

This collaborative small research leads to further curiosity. Among others is the modeling of the annual air passenger demand growth for several years, the air passenger demand variation due to the Covid-19 pandemic, the embarking air passenger arrival distribution, the air passenger demand trip distribution, the air cargo volume variation, the air cargo demand distribution, the air passenger transport connectivity in Tanzania, a good method to develop an index of variation for air passenger volume, general financial analysis of commercialized airport, etc.

NOTE. This paper is a result of a reflection collaboration among a Tanzanian Engineer from Tanzania CAA, and two Indonesian Engineers from ITS and UGM. This is part of working papers for developing the sciences and pieces of knowledge of Airport Asset Management.

\section{REFERENCES}

ACI (2019). ACI Annual Report 2019, https://store.aci.aero/form/aci-annual-report-2019/ Ahyudanari, E. \& Vandebona, U. (2009). Design of Airport Check-in Area: An Alternative Method. VDM Verlag. Germany.

Arblaster, Margaret (2018). Air Traffic Management: Economics, Regulations, and Governances. Elsevier. Amsterdam/

Çuhadar, Murat (2014). "Building Proper Forecast Model for Daily Passenger Demand: A Study of Antalya International Airport". Conference Proceedings - International Antalya Hospitality Tourism and Travel Research, Porto Bello Hotel, Antalya, Turkey, 9-12 December 2014.

Hamzah, Dewanti, Muthohar, I. (2020). "Evaluation of Terminal Service Evaluation at Mopah Class I Airport Merauke”. Jurnal Manajemen Aset Infrastruktur \& Fasilitas 4(2) April 2020.

Horonjeff, R. \& McKelvey, F.X. (1994). Planning and Design of Airport. Fourth Edition. McGraw-Hill Inc. New York.

ICAO Doc. 7910. ICAO Doc 7910, Location Indicators, 165th edition, September 2017. International Civil Authority Organisation (ICAO)

Lestari, Dewanti, Priyanto, S. (2020). "Factors Affecting Air Transport Route Development of Sumenep-Surabaya Vice Versa". Jurnal Manajemen Aset Infrastruktur \& Fasilitas 4(2) April 2020.

Madhwal, Y., Avdeeva, Z. (2017). "Planning in the Aircraft Industry Based on Prediction of Air Traffic". Information Technology and Quantitative Management (ITQM 2017). Procedia Computer Science 122 (2017) 1047-1054.

Mao, L., Wu, X., Huang, Z., \& Tatem, A.J. (2015). "Modeling Month Flow of Global Air Passenger: An Open-Access Data Resources". Journal of Transport Geography 48 (2015) 52-60.

Robertson, F. \& Wallin, M. (2014). Forecasting Monthly Air Passenger Flow from Sweden. Bachelor Thesis. Department of Statistics. Uppsala University. Uppsala.

Sartono, W., Dewanti \& Rahman, T. (2019). Bandar Udara: Pengenalan dan Perancangan Geometrik Runway, Taxiway, dan Apron. UGM Press. Universitas Gajah Mada. Yogyakarta.

Sefrus, T., Priyanto, Sigit, Dewanti \& Irawan, Muhammad Zudhy (2020). "Modelling of Air Passenger Demand in The Papua Island". Songklanakarin J. Sci.Technol.42 (5), 1072 1077, Sept-Oct 2020.

Soemitro, R.A.A. \& Suprayitno, H. (2018). "Pemikiran Awal tentang Prinsip Dasar Manajemen Aset Fasilitas". Jurnal Manajemen Aset Infrasruktur \& Fasilitas, 2(Suplemen 1), Juni 2020. 
Suprayitno, Pambudi \& Cahyono (2017). "Preliminary Modelling for Ship Passenger Arrival Distribution, Case of Gapura Surya Nusantara Passenger Terminal, Tanjung Perak Port, Surabaya". Proceedings of the Eastern Asia Society for Transportation Studies, Vol. 11, 2017.

Suprayitno, H. \& Soemitro, R.A.A. (2018). "Preliminary Reflexion on Basic Principle of Infrastructure Asset Management". Jurnal Manajemen Aset Infrastruktur \& Fasilitas 2(1) March 2018.

Suprayitno, Hitapriya (2020). "Investigating the Utilisation of Different Variables for Direct Gravity Trip Distribution Model for Air Passenger Demand". Atlantis Press: Advances in Engineering Research, 25 February 2020, $2^{\text {nd }}$ International Symposium on Transportation Studies in Developing Countries (ISTSDC 2019).

Suprayitno, Hitapriya (2020a). "Developing a Direct Gravity Trip Distribution Model for Air Passenger Demand". IOP Conference Series: Earth and Environmental Science 419(1), 012092.

Suryani, E., Chou, S-Y., Chen, C-H. (2010). "Air Passenger Demand Forecasting and Passenger Terminal Capacity Expansion: A System Dynamic Framework”. Expert System with Applications 37 (2010) 2324-2339.

TCAA (2020). Aeronautical Information Publication 2020. Tanzanian Civil Aviation Authority.

Teodorovic, D. \& Janic, M. (2017). Transportation Engineering Theory, Practice, and Modeling. Elsevier. Amsterdam.

Wang, P.T., Pitfield, D.E. (1999), "The Derivation and Analysis of The Passenger Peak Hour: An Empirical Application", Journal of Air Transport Management, Vol. 5, Issue 3, July 1999, page 135-142. 
e)ISSN 2656-8896 (p)ISSN 2656-890X

Journal of Infrastructure and Facility Asset Management - Vol. 2, Issue. 2, September 2020 